\title{
An Analysis of the Employment Situation and Countermeasures of Russian Graduates under the Sino-Russian Cooperative Education Model-----Take the School of Public Foreign Language of Beihua University as an Example
}

\author{
Xiaoyu Han
}

\author{
School of Public Foreign Language, Beihua University, Jilin 132000, China; \\ 108735748@qq.com
}

Keywords: Sino-Russian joint training model; Employment status; Countermeasure analysis

\begin{abstract}
At present, the difficult employment for university students has been the focus of social concern, especially Russian. This paper takes the School of Public Foreign Language of Beihua University as an example to discuss the employment situation of students in the last three years under the Sino-Russian joint training model, analyzes the causes of students' employment difficulties, and strives to solve the problem of "difficulty in employment" in practice.
\end{abstract}

\section{Introduction}

The employment problem of college students has always been a hot issue of concern in the academic world, and there have been many studies on the employment of college students. However, the employment situation of students under the Sino-Russian joint training mode presents some characteristics different from the past. In particular, with the implementation of the national strategy of the "Belt and Road". This paper sorts out the graduation situation of students in the past three years, trying to start from the theoretical and practical aspects, to explore the causes of student employment difficulties in a specific context, and strive to propose solutions to the problem.

\section{The employment direction of Russian graduates.}

Engineering. Relying on the "Belt and Road" initiative, China and Russia have extensive cooperation in the construction of infrastructure such as oil and gas pipelines, cross-border bridges, transmission lines, and optical cable transmission systems. [1] It has also led to large domestic engineering projects abroad. Such foreign projects require Russian professionals to do translation work. The Russian translation of engineering works has a higher salary, but it requires students work outside and a rather harsh working environment. This is why many overseas projects tend to recruit male students.

National Public Service. The number of Russian professional graduates recruited by state public agencies is relatively small and concentrated. It is usually in the ports of the three northeastern provinces or Inner Mongolia. Affected by traditional ideas, most graduates choose such stable and decent jobs. Therefore, if Russian graduates want to stand out in the fiercely contested national exams, they will be very difficult.

Tourism performing company. With the development of the domestic tourism industry and the rapid growth of the Russian economy, the number of tourists from China and Russia is increasing, especially more and more Russians go to major Chinese performing companies for gold [2]. However, at present, the Russian language students in the domestic tourism industry are still relatively scarce. As a salary for Russian translation is relatively low, it is not a good choice for the individual's long-term development. This results in the need of the buyer and the seller does not want to go.

Foreign Enterprise Translation.Many large state-owned enterprises or relatively large private enterprises engaged in the trade of goods with Russia also need professional Russian translators. However, due to the relatively high requirements of knowledge in foreign trade and the strong professionalism, Russian graduates need to learn to supplement a large amount of trade and legal knowledge while working. Although the salary is relatively high, the work pressure is high [3] . 
School.The college has two majors: Russian and Russian (teacher). Most of the students who study Russian (teacher) major want to be engaged in the teacher profession. From the three northeastern provinces, there are fewer and fewer schools that offer Russian in elementary schools or high schools. There is no way for students to apply for other professional teacher qualifications, which in turn causes the students to work inconsistent with their studies in the employment process, which increases the difficulty of student employment.

Other non-professional.In view of the difficulty of employment in this profession, students will choose to change their profession and go to non-Russian majors such as clerk, sales, real estate and media.

\section{The status of employment of Russian undergraduates}

The level of student employment is not high enough.Due to the low visibility of the school, students are hard to be favored by large state-owned enterprises and institutions during the employment process. The number of Russian-speaking professional employers is small, and the main employment of students is small enterprises and companies, and most of them are not engaged in this profession.

Table 1 Employment Statistics for Russian Undergraduates

\begin{tabular}{|l|c|c|c|}
\hline Years & 2015 & 2016 & 2017 \\
\hline Number of graduates & 56 & 56 & 60 \\
\hline Number of professionals & 17 & 19 & 23 \\
\hline Number of non- professionals & 33 & 32 & 35 \\
\hline Number of unemployed & 6 & 5 & 2 \\
\hline
\end{tabular}

As can be seen from Table 1, in 2015, the student's match rate was $30.36 \%$, in 2016 it was $33.92 \%$, and in 2017 it was $38.33 \%$. The data shows that in the past three years, the Russian counterparts have consistently maintained a relatively low level of their counterparts, indicating that students' recognition of the profession is not high during the learning process and the employment situation is worrying.

Personal qualities of students are not better. Students must pay attention to cultivating their own professional skills in the professional learning process. They must love their majors and be able to actively and optimistically study. According to the statistical data of employment units in our school in 2017, this article lists 5 data of 10 companies.

Table 2 Statistics of employers and graduates

\begin{tabular}{|l|c|c|c|}
\hline & Company & $\begin{array}{c}\text { Number of people who } \\
\text { meet the requirements }\end{array}$ & Percentage \\
\hline Overseas & 4 & ----- & ----- \\
\hline Male & 7 & 7 & $11.66 \%$ \\
\hline Have a study abroad background & 8 & 32 & $53.33 \%$ \\
\hline Good oral Russian & 6 & ----- & $30 \%$ \\
\hline $\begin{array}{l}\text { Academic scores account for 30\% } \\
\text { of the college's total }\end{array}$ & 4 & 18 & \\
\hline
\end{tabular}

It can be seen from Table 2: The employment situation of Russian professional male students is better than female students. Many foreign institutions require boys, but the proportion of male students in the class is very low. Half of the companies require the students who studying aboard. The employer's emphasis on students' academic performance is not too high, which reflects the employer's emphasis on students' ability to apply language. The direction of employment of Russian-speaking students is divided into two aspects. One aspect is the requirement for transnational corporations to be stationed abroad, and the other is tourism and performing arts centers engaged in translation work.

The students' willingness to apply for jobs is not strong enough. In the survey of students' employment intentions, they found that some students did not have a strong desire to find a job. The 
expectation of some employers was too high and they wanted to be in one step. In addition, most of the students' job-hunting expectations are concentrated in the stable, high-income industries such as public organizations, large state-owned enterprises, or non-central cities [4]. The Result is a lot of job opportunities missed.

Student picking up employment information channels are not wide enough.It is understood that the main channels for students to obtain information are the school's campus job fairs, external recruitment websites, and college teacher's recommendations. For a start-up major, the fame of the college is low, many enterprises employers do not learn more about school and there are not many professionals who come to the school to attend the job. The students' access to employment information is too narrow, which affects the employment of graduates. Enthusiasm.

\section{Employment Strategy Analysis of Russian Professional Graduates}

In order to improve the employment rate of students in our college and improve the employment level of students, in the current situation, we must take the market demand as the orientation, flexibly adjust the training mode of talents, establish a reasonable training system, improve the quality of students, and create "one specialty bilingualism and multiple-abilities " [5] complex training model satisfies the society's requirements.

Improve students' own quality. The student's own qualities include ideological and moral qualities, scientific and cultural qualities, physical, psychological qualities, and professional knowledge. First of all, many employers use the spirit of ideological and political quality and hard-working dedication as the primary goal of selecting graduates [6]. Second, professional knowledge, once a college student determines his ideal career, he will plan his own learning and practice based on his career goals, and be prepared to obtain an ideal career. Students can only be invincible by uniting a reasonable knowledge structure and various capabilities of the applicable society. Third, cultivate good psychological qualities and improve employability. College students bear the heavy responsibility of building the motherland and are the backbone of society. During the period of study, college students only pay attention to professional knowledge and ignore the psychological quality, so that when people are faced with confusion or adversity, they are always overwhelmed and affect their choice of career. In particular, during the job search process, some students have poor anti-frustration ability, which is one of the reasons why our college students find employment difficult. Therefore, college students should pay attention to improving their psychological quality in the process of studying, especially in daily life, pay attention to exercise their own perseverance and unyielding personality [7] ; at the same time, in the job search, full understanding of employment information, calm and response to the difficulties with a positive and optimistic attitude.

Innovative employment guidance. According to a survey conducted by the China Youth Daily, a survey of 1973 college students or graduates showed that $92.1 \%$ of the surveyed college students hope that the school will increase their employment guidance and help for the students. The interviewed college students want to have career development., career orientation, decision making, etc. $52.6 \%$ of the interviewed college students suggested that college employment guidance is for all grades of students, and $51.2 \%$ of the surveyed college students hope to innovate the content and form of the career guidance curriculum. Therefore, as a college counselor and professional teacher to move forward with employment guidance, conduct career planning education for first-year students, interview training for sophomores, help students prepare and practice as early as possible, in order to cope with multiple abilities In accordance with the requirements and assessments, senior students and senior students are guided by categories such as postgraduates, employment, and civil servants. According to the different needs of different employers, they are analyzed one by one to achieve seamless integration between students and employers.

Broaden Employment Information Channels. The acquisition of employment information by students determines the quality of student employment. Therefore, a variety of student employment information is required. First, do a good job in policy advocacy. College teachers need to use the 
easy-to-understand methods of the country's employment and entrepreneurship policy, and the recruitment of soldiers to communicate to each student in the class through various channels. Second, it is necessary to take the initiative to contact employers to obtain timely feedback and invite employers to report for students. Third, fight for alumni's help. In 2018, our school alumni Himalayas successfully signed more than 30 professional graduates of our school. Fourth, it is recommended that students pay attention to employment information through online channels, and at the same time, remind students to enhance their awareness of prevention and improve their ability to distinguish between the authenticity of employment information.

Improve Sino-Russian Joint Training.The college adopts the Sino-Russian joint training model and should pay more attention to the advantages of educational resources between China and Russia. First of all, with the continuous improvement of the language level of foreign students studying in Russia, on the basis of the original " $2+2$ ", we actively explored various modes such as " $3+1+2$ " and " $1+3$ " [ 8$]$. Second, by introducing Russian professional teachers, teaching materials, curriculum plans, teaching methods, and other high-quality resources, students can enjoy high-quality education and teaching resources abroad during their studies in China. In accordance with the requirements of training programs, language training and foreign characteristics The professional curriculum learning is conducted synchronously, allowing students to adapt to foreign teaching methods and management methods as soon as possible, so as to provide assistance for the improvement of students' professional skills [9].Third, encourage, support, and guide students to study Russian master students. In order to achieve a high level of language proficiency, students are encouraged to apply for postgraduate studies abroad to provide a broader perspective for employment. In 2015, there were three students studying for post graduate in our college. In 2016, there were three students studying for post graduate. In 2017 , there were four students studying for post graduate and in 2018 there were seven students studying for post graduate. Post graduate students engaged in translators such as Haier Group. They have better employment levels and better treatment [10]

\section{Summary}

This paper sorts out the employment directions of students under the Sino-Russian joint training model in the past three years, analyzes the current employment situation of students under this model, and the reasons for employment difficulties, and puts forward solutions to the problems of the college's actual situation. We hope to provide useful lessons for the employment of Russian-speaking students. We also hope that Russian-speaking graduates will be able to use the "Belt and Road" international situation to improve their professional skills and become a useful Russian-language talent for social development.

\section{References}

[1]P.Wang: The road to scientific researchp. 2010 No 5, p.57-61(In Chinese)

[2] Niklas Swanstrom: Taylor\&Francis Journal,2014Vol23p.480-497

[3] V.F.Pugach,E.A.Federovna: Russian Education\&Society,2012No54, p.80-98

[4]S.Li: Journal of Social Science of Jiamusi University, 2010 No3, p.124-125(In Chinese)

[5] X.Y.Dai:The Science Education Article Collects, 2014 No5, p.43-44(In Chinese)

[6] L.S.Chen:Human Resources, 2017 No10, p.143-144(In Chinese)

[7] H.M: Theoretic Observation,2011No4, p.152(In Chinese)

[8] Y.T: Teaching Russian in China,2016No3, p.92(In Chinese)

[9] X.Y.Lui:Journal of Heilongjing College of Education, 2014 No9, p.196(In Chinese)

[10] Y.Lui:Journal of Higher Education, 2017 No20, p.17(In Chinese) 